\title{
Heterodox Views on the Elements according to Buddhist Testimonies
}

\author{
Robert Duquenne
}

The analysis of objective reality has, in Indian philosophy, recognized to the Elements an important function in the formation of both the phenomenal world and the senses perceiving it. The first part of this study will concern the phenomenal world ${ }^{1}$.

Parallel to the insight relating to the body 念身 (kāyagatāsati), which considers six constituent parts of individuality 六界 (șaḍ dhātavah: earth, water, fire, wind, space and knowledge), certain texts in the Nikāya add an analysis of the phenomenal reality as composed by four Elements 四大種 (catvara mahābhūtāni: earth, water, fire, wind) ${ }^{2}$. Excluding that space and knowledge could be “outer” 外 (bāhya) Elements, Theravāda Buddhism comes to a theory close to that of the Materialistic (Lokāyata) school while it intends to differentiate itself form the current theory on the five Elements, which has been adopted in the Prajñāpāramitā tradition"). The Materialistic school, "relying on common sense” 順世 (lokāyata) ${ }^{4}$, accept only four Elements, since only four are given by experience, and no reality beyond the sheer total of the components ${ }^{5)}$. Certain would profess that only the Elements, and no retribution owing to a previous karma, stand for the permanence of a psychic activity ${ }^{6}$, or that knowledge or mind, as a mere product of their timely collusion 和合, disappears as soon as this collusion ceases and can not assume a transmigrant function ${ }^{7)}$. This latter view, as well as its hedonistic consequences, appears to have been held by Ajita Kesakambalin and Pakudha Kaccāyana or Purana Kassapa ${ }^{8)}$, "heretical" masters who would have lived in the time of Sākyamuni and answered to King Ajātaśatru's question on the fruits of ascetic life.

The first would profess that, when comes the term of life, the four inner Elements 
return to their outer counterparts, and the faculties 根 (indriyāni) to the space9). The second, that the four Elements, together with ease (sukham), pain (duhkham $)^{10)}$ and the soul (jivam), would only gather as a bunch of reeds: a sword would only penetrate into the interval between these seven elemetary substances. This forceful expression has been adopted by later Buddhists to illustrate the opposite, that killing the body does not kill the knowledge, the psychic principle of rebirth ${ }^{11)}$, or to show that the Bodhisattva remains undisturbed ${ }^{12)}$. Whatever be these later developments, it should be noted that early Buddhism, as far as it is concerned with an analysis of the outer world, concords with a positivist current in Indian thought which attributes the formation of all objective reality to the interaction of four Elements endowed with specific qualities. This current marks a striking difference with earlier cosmologies based on one, two or three primordial forces of a rather mythic nature ${ }^{13)}$, in the new possibility it gives for a positive explanation to substantial differences and transformations as can be observed in objective reality. The Elements have, at least implicitly, been considered since an early period to stand respectively for the qualities of compactness and solidity (samghāta, kharatvam) viscosity and cohesion (sneha, dravatvam), heat (uṣnatā), and movement (ïraṇa)14). Moreover, the simultaneous presence of these qualities in matter as well as the tranfomations matter as a whole may undergo, suppose that the Elements are all four indissociable 不相離 (avivekhin) within the matter compound and exert on it an action in which each one takes its share ${ }^{15)}$. This share, according to the nature of the matter compound, may be more or less prevalent, which explains the possibility of different substances and the different stages in the transformation of a same substance. Such an explanation could hardly be worked out if the Elements are to be considered only as the substances after which they are named. Hence, an essential differentiation between Earth and earth, etc. has been clearly defined in the Abhidharma ${ }^{16)}$, but it could hardly be precised to what extend it was elaborated in other philosophical systems, namely among the materialist philosophers contemporary to Śäkyamuni.

This difference is still deeper with the atomic theory on which the analysis of matter and of its transformations is based, a theory that follows roughly a 
double pattern. A first one, where the most subtle particle (paramānu) contains. all four (or five) Elements ${ }^{17)}$, whether these Elements are sensible only to touch or correspond respecively to the five organs of perception, A second one, "Akkumulationstheorie" (Frauwallner) ${ }^{18)}$, where the number of composing Elements grows according to the perceptive nature of the particle. The first system is common to Buddhism and early Sāmkhya and Vaisesika, but the latter admits. specific and immediate relations between Elements and organs, whereas the former consider only the tangible character of the Elements. The Akkumulationstheorie has been developed by the Sāmkhya and subsequently adapted by the Vaiśesika school. The relation between organs and Elements according. to both systems and their variants will be discussed, together with Buddhist criticism, in the second part of this article.

1) The second part is to be presented at the Congress of Indian and Buddhist Studies in 1978.

2) Majjh. N. I $185-190=T$ I 26 vir $n^{\circ} 30,464 \mathrm{c} 3-466 \mathrm{~b} 21$, T II $125 \mathrm{xx} \mathrm{n}$ 4, 652a16b11 e. a. Though the mahābhūtāni are of te called dhātavaḥ, the reverse hardly occurs, cf. article Dai 大 in Hōbōgirin VI.

3) This exclusion is explicitly made in the Vibhāṣa: T XXVII 1545 cxxvII, 662b 19-c5, T XXVIII 1555 I, 990a7-15; cf. T XXIX 1562 II, 336a6-b1, 1563 II, 782c110. This does not mean that the rejected theory on the five Elements was more ancient: cf. E. Frauwallner. Geschichte der Indischen Philosophie, Salzburg 1959. I p. 109, 289-290.

4) On the origin of the name lokāyata, cf. G. Tucci, Linee di una storia del materialismo indiano, reed. in Opera Minora, Rome 1971, I p. 72-73.

5) Hence the critic in $\mathrm{T}$ XXX 1571 II, 195c15-196a9, which objects that the distinction between male and female is not a quality present in the components. Tucci, op. cit. p. 129.

According to the Vijñāptimātrasiddhi, they say that to conclude from the permanence of the Elements of their compound, gross matter, would exceed the causal extension 因量 of the Elements (T XXXI 1585 I, 3b19-20, td. La Vallée-Poussin, Paris 1928, I p. 32-35). It seems doubtful wether the Lokāyata expressed their view in such nominalistic terminology as to define the matter compound as mere words (vāgmātratvāt) : cf. Lañkāvatāra-s, ed. Nanjio, p. 208 l. 1-4, T XVI 670 Iv, 508c20-23, 671 vir, 554a26-29, 672 v, 618a6-12, T XXXIX 1791 II, 445c22-25.

6) T XXVII $1545 \mathrm{cIV}, 536$ a 22-b8, T XVIII 1546 LIV, 387a6-13.

7) Prasannapadā XVIII, ed. La Vallée Poussin, p. 358; td. de Jong, p. 16. T XXXIX 
1591 II, 445c1-7, v, 467c1-17, cf. Buddhacarita XII, 72-73=T IV 192 III, 23c28-24a3. E. Frauwallner, op. cit. I p. 130.

8) Digha Nikāya I 55-56=T I 1 , xviı $n^{\circ} 27,108 \mathrm{~b} 23-\mathrm{c} 1$ : for other references and on the attribution of the two teachings concerning the Elements among the six heretical views, cf. Ui Hakushu 宇井伯壽, Indo tetsugaku no kenkyū 印度哲学の 研究 II, Tōkyō 1965, p. 352-355, B. C. Law, Influence of the five heretical teachers on Jaïnism and Buddhism, Journ. Roy. As. soc. of Bengal XV (1919) p. 131-132, G. Tucci, art. cit. p. 140-142, B. M. Barua, a History of Pre Buddhistic Indian Philos. Calucutta 1921, repr. Delhi 1970, p. 282, 293. It should be added that the Nirvāna-sūtra ( $T$ XII 374 xIx, 474c18-27=375 xvII, 717c8-18) attributes the second teaching to Maskarī-gosāliputra and that, in general, the sarvāstivāda tradition as well as the tibetan texts and, the first chinese version of the Sāmaññaphala (T I 22, 271b19-c6) attribute the first one to Pūraṇa Kassapa. Indeed, the theories were more known than their authors, who are seldom named, and personal attributions remain delicate. Nor should it be taken for granted that these masters are the ancestors of the Lokāyāta school. See Kumoi Shōzen 雲井昭善, Journal of Ind. and Buddh. Stud. (IBK) V, 1 (jan. 1957) p. 180-181, and IBK. LX. 2 (march 1961) p. 26-27.

9) This has often been interpreted in the mystic sense of non-duality between the individual and the cosmos. Reference in Hōbōgirin VI s. v. Dai 大.

10) B. M. Barua, op. cit. p. 282 compares the alternative action of sukha-duhkha


cf. G. S. Kirk and J. E. Raven, the Presocratic Philosophers, Cambridge 1957, reed. 1973, p. 328-329.

11） T LII 2102 v, 33b10-34a6, cf. Kajiyama Yūïchi 梶山雄一, Eon no hōōsetsu to shinf umetsuron 慧遠の報応説と神不滅論, in Kimura Eiichi 木村英一 ed. Eon kenkyū 慧遠研究 I, Kyōto 1962, p. 115-118.

12) $\mathrm{T}$ XV 586 III, 53b1-6, v, 86b10-16, T XL 1813 iv, 633a6-8.

13) Most of the Buddhist critics concern the cosmologies based on one Element. $T$ I 1 xx 136a14-137a23 (without pāli equivalent), T I 23 Iv, 299b7-300a19, T I 25 viI, 403b26-404c1, T XXV 1509 xxxiI, 299c1-300a19, T XXXII 1640, 157a7-10, 158a17-29; cf. E. Frauwallner, op. cit. I p. 49 sq. The similarity with presocratic philosophers, namely Thales and Anaximenes, has been pointed out by earlier scholars to show the contrast with the Buddhist point of view: see Inoue Enryo 井上圓了, Gedō tetsugaku 外道哲学, Tōkyō 1897, p. 299-306. There may be no historical evidence for a direct influence, and no way to define in which sense such an influence would have worked, if it worked at all before the hellenistic period. Still, similitudes of view on concrete points which do not resort to common sense may allow a comparative study, provided that such a study be based on a sound textual analysis of both similitudes and differences. See G. S. Kirk 
and J. E. Raven, op. cit. p, 87-89, 151-153.

Reference to systems of two, three or five Elements: R. Garbe, Die Sāmkhya Philosophie, Leipzig 1894, p. 273-274, Frauwallner, op. cit. I p. 89-94.

14) E. Frauwallner op. cit. II p. 29. see below note 18 on these qualities in the Sāmkhya and Vaiśesika traditions.

It has been said (Sakurabe Hajime 桜部健, Kusharon no kenkyū 俱舎論の研究, Kyōto 1969, p. 94-96 e. a.) that these qualities appear as the essences of the Elements only in Abhidharma, or even that Abhidharma tradition is the first to name them. This has still to be confirmed by a chronological study of their first occurences in non-Buddhistic philosophy. Moreover, the aim of the first Sutras and of the Abhidharma-exegesis are quite different: the analysis of the Elements 分別界 (dhātuvibhanga) in the Sūtras is one of the insights relating to the body 念身 (kāyagatāsati) in its impermanence and its impurity, a meditation practice on its solid, liquid, hot, airy, empty and psychic substances or entities. These categories, at least the first four, appear already in Āyurveda, cf. Hōbōgirin s. v. Byō 病, S. Dasgupta, A History of Indian Philosophy II Cambridge 1932, reed. 1952, p. 288 sq., J. Filliozat in L. Renou e. a., l'Inde Classique, I Hanoï 1953, $\S 1951$; Encyclopaedia of Buddhism, G. P. Malasekara ed., Ceylon Gvr. Press, III, 2 s. v. Body, p. 256b. I did not yet consult Grundriss der Indo-Arischen Philologie III, 10 (Jolly). On the other side, Abhidharma is really concerned with explicit definition and classification of all the dharmas. The solid, etc. substances in the body are of course not identic with earth, etc. but have a common quality with earth, fire and wind respectively, a quality which has metaphorically be named as Earth. Hence the terminology adopted at Aung's suggestion by the Pāli Text Society translators: Extension, Cohesion, Heat and Movement, even for the Nikāyas. See also Majjh. III 239-242=T I 26 xLII n ${ }^{\circ} 162,690 \mathrm{~b} 22-691 b 5$, Majjh. I 185-190=T I 26 vir $n^{\circ} 30,464 \mathrm{c} 3-466 \mathrm{~b} 21$; T XI 310 LXxiII, 414c8-417a9, 320 xxvi, 949c3-965c6. References to Abhidharma: T XXVI $1537 \mathrm{x}, 502 \mathrm{c} 24-503 \mathrm{~b} 21$, T XXVII $1545 \mathrm{xxv}$, 387c14-389b6=T XXVIII 1546 xxxix, 290c1-291c10, 1547 vi, 460b10-461c2; T XXVI 1542 ı, 692c11-12, 699c4-7, T XXVIII 1549 i, 722a2-5, v, 754c10-21, 1556 r, 995c 24-26, Abhidharma-kośa ed. D. Shastri, p. 42 (ed. P. Pradhan, p. 8)=T XXIX 1558 I, 3b8-13=1559 I, 163c25-164a1. Dhammasangani §962-965, T XXXII 1648 viI, 438c4-440b13, Visuddhimagga XI, 347-370. cf. Nārada, a Manual of Abhidhamma, Kandy 1968, p. 282, Y. Karunadasa, The Buddhist Conception of Mahabhutas, Univ. of Ceylon Review XXII, 1-2 (april-october 1964) p. 28 sq.

cf. R.Garbe, Die Sāmkhya Philosophie, Leipzig 1894, p. 239 on the qualities of dhārana. kledana, pācaka, śoṣaṇa and avakāśa-dānena inSāmkhya-krama-dīpika, 32.

15) This indissociability is proved in a negative way by the Garbhāvakrānti-sūtra: T XI 310 LV, 322c11-20, LvI, 328c14-27=317, 866c5-28, T XXIV $1451 \mathrm{xI}, 253 \mathrm{c} 24-$ 254a10, T XXVII 1545 cxxvir, 663b8sq., T XXVIII 1550 iv, 827a12-21, 1551 v, 860c 
21-861a2, 1552 vin,936b16-22, 1553 I, 971b13-21, T XXIX 1558 i, 3a28-b13=1559 I, $163 \mathrm{c} 22-164 \mathrm{a} 2,1562 \mathrm{I}, 336 \mathrm{~b} 4 \mathrm{sq}$. which attributes to the four Elements the action of holding 持, of collecting 摄, of maturing 熟, and of raising 增長 the embryo (kalalam). This sūtra seems to be in relation with Pudgalavāda and Vijñānavāda traditions.

Another version appears in T XXVII 1545 Lxxv, 387a22-c13=T XXVIII 1546 xxxIx, 290a16-b26.

Owing to their specific activities, the Elements are considered rather as forces (samskara) than as substances (dravya), cf. Th. Stcherbatsky, the Central Conception of Buddhism, London 1923, reed. Calcutta 1961, p. 18, Y. Karunadasa, art. cit., p. 28.

16) Distinction between the Elements and their counterparts in reality:

T XXVI 1543 xIx, 859a17-20, 862a21-26=1544 xiI, 968c26-29, T XXVII 1545 cXxxII, 689a13-b23, T XXVIII 1552 ıx, 949b22-c2, T XXIX 1558 ı, 3b17-22 1559 I, 164a3-6, 1562 II, 336c23-337b8, 1563 II, 782c15-783a9, TXLI 1821 Iв, 23a29-b17=1882 Iв, 483b28-c10, Kośa ed. Shastri p. 43 (ed. Pradhan, p. 9), td. La Vallée-Poussin I, p. 23. Cf. S. Aung-C, A. F. Rhys-Davids. Compendium, p. 268-271 (this distinction is not explicitly made in the Theraväda tradition). According to Kośa, it relies. on a distinction made between common and higher sense: T XXIX 1558 xxII, 116b12=1559 XVI, 268c10, ed. Shastri, p. 889 (ed. Pradhan, p. 333), cf. T XXVIII 1553 I, 971b14-21. See different explanations in T XXVII 1545 cxxvir, 664c16-27 and T XXXII $1648 \mathrm{x}, 446 \mathrm{b3}-4$.

17) One theory considers each gross Element as composed by five subtler ones in proportion of $1 / 2$ for the predominant subtlc one caracterising its gross counterpart and 4/8 for each of the four others. Cf. A. B. Keith, the Sāmkhya system, Calcutta-London 1924, p. 93, H. Zimmer, Philosophies of India, New York 1951, reed. 1961, p. 327-328 n. 51, quoting Bhāratītīrtha's Pañcadaśi I, 27.

The Buddhist view is that each "atom" (paramānu) is composed by four Elements in equal proprotion, that the qualities of the Elements are all perceptible in that "atom," and exclusively tangible. Cf. Atthasalinī, 312-313, Visuddhimagga XIV, 444 contra T XXXIII 1648 x, 445c26-446a15, Ñānamoli. the path of Purification, p. 491 n. 16-18; T XVII 721 xxxIII, 191c12-15, whereas Vaiśesika and Samkhya consider an immediate relation between particular Elements and organs, see part II. of lhis azticle.

18) Frauwallner, op. cit. I p. 109, 122-123, 289-290, 335-358, II p. 32. 